\title{
TRYPARSAMIDE IN THE TREATMENT OF SYPHILIS OF THE NERVOUS SYSTEM *
}

By FRANK E. CORMIA, M.D., Instructor of Dermatology and Syphilology, School of Medicine, University of Pennsylvania, Philadelphia.

\section{TRYPARSAMIDE}

SINCE tryparsamide was synthesised by Jacobs and Heidelberger eighteen years ago there has evolved a slowly changing conception of its modus operandi. The early experimental studies by Brown and Pearce, in which they predicted the principal actions of tryparsamide in human infections, were followed by the basic clinical investigation, by Lorenz and his co-workers, of the value of tryparsamide in the treatment of syphilis of the central nervous system. One significant fact immediately became apparent, namely, that late central nervous system syphilis, which had previously resisted long sieges of standard treatment for syphilis with arsphenamine, neoarsphenamine, the various intraspinal techniques, and mercury and the iodides, was now responding to this new form of treatment.

\section{Mechanism of Action of TRyparsamide}

The exact mechanism of the action of tryparsamide is unknown. It stimulates natural resistance and has a well-recognised tonic effect. It has, as Moore has shown, no spirochæticidal action in man; and he found it absolutely valueless in primary, secondary and tertiary syphilis of the skin, and in osseous or visceral syphilis.

The effectiveness of tryparsamide depends, I believe, upon its superior penetrative power for the tissues of the central nervous system. Voegtlin arrived at this conclusion indirectly, deducing it chiefly from the fact that tryparsamide was therapeutically effective with rabbits whose brains were infected with trypanosomiasis.

* From the Department of Dermatology and Syphilology, School of Medicine, University of Pennsylvania, Philadelphia, Pa., John H. Stokes, M.D., Director. 


\section{BRITISH JOURNAL OF VENEREAL DISEASES}

Mehrtens, and later Cornwall, Bunker and Myers, estimated the amount of tryparsamide penetrating the cerebro-spinal fluid. Mehrtens reported large amounts, while Cornwall et al. found only relatively small amounts. Fordyce et al., working with rats, tried to determine the amount of arsenic in dried brain substance. They concluded that tryparsamide had no penetrative power for the nervous tissue. Osborne, however, has made a very pertinent criticism, and believes that " one cannot tell how much arsenic is present in the blood of an organ after death, how much blood is in the organ, and how much arsenic has penetrated the cellular tissue of the organ." Working with a micro-chemical method of estimation of the number of crystals of arsenic trioxide seen in a given section of prepared tissue, he apparently demonstrated that, following the administration of tryparsamide, appreciable amounts of arsenic were present in the parenchyma of the brain and spinal cord. It would seem then, as Solomon has stated, that tryparsamide has a local effect, working within local areas of the nervous system, but just what that effect is we do not know.

\section{Material and Methods of the Present Study}

This series is composed of 75 cases of neurosyphilis. Of these 75 cases, 44 form the basis of this study, and have each received more than twenty injections of tryparsamide. The total number has been used only in estimating the percentage of ocular damage. Of the 44 cases completely studied, 33 were males and II were females. The average duration of the disease when the patient was first seen was :-

(a) 9.7 months in six patients with early neurosyphilis and

(b) Sixteen years in 38 cases of late neurosyphilis. The average duration of treatment with tryparsamide was two years, the average number of injections of tryparsamide was fifty-eight. Injections were given, with but few exceptions, continuously, and at weekly intervals. From one to five courses of an insoluble bismuth preparation, each course consisting of approximately twenty injections, were given concomitantly in most of the cases. All of the cases had previously received 
varying amounts of standard treatment for syphilis, seven had received typhoid vaccine (with very little benefit), three had received malaria, and three others had been treated by the Swift-Ellis method.

\section{Results of Present Study, in Comparison with those of Previous Investigators}

\section{(I) Early Neurosyphilis.}

Tryparsamide therapy has been only partially effective and reliable in early neurosyphilis. Moore and his coworkers have cited several muco-cutaneous and neurorelapses from their early material. Moore, Stokes, O'Leary and Solomon routinely give prolonged standard treatment with arsphenamine and bismuth. However, Solomon states that "If cases with early nervous system involvement, with a paretic type of serology, do not respond to standard therapy, they should be placed at once on tryparsamide or malaria, if definite late neurosyphilis is to be avoided."

Hopkins, in a recent analysis of the Johns Hopkins material, found an 85 per cent. clinical and a 64 per cent. serologic cure. But these percentages apply to treatment with standard, followed by tryparsamide, therapy.

In the present series there were five patients with early neuro-syphilis, in each of whom a paretic type of spinal fluid had been obtained. The average number of tryparsamide injections was sixty-six. Each patient had previously been treated with considerable amounts of arsphenamine and heavy metal. In three patients the spinal fluid ultimately became negative, in one it was reduced and in one it was unchanged. One patient who had previously received sixty-one injections of bismarsen, four of old arsphenamine and forty of bismuth developed a left facial paralysis and a paretic type of serologic relapse after forty-nine injections of tryparsamide. The paralysis soon cleared, and the spinal fluid became negative after fifty-five more injections of tryparsamide. Another patient who had previously received thirty-four injections of arsphenamine (6o6), twenty-three injections of bismuth and seventy-six mercury rubs had a paretic type of serologic relapse after I04 injections of tryparsamide.

(2) Meningo-vascular Syphilis. 


\section{BRITISH JOURNAL OF VENEREAL DISEASES}

\section{Results obtained by previous Investigators}

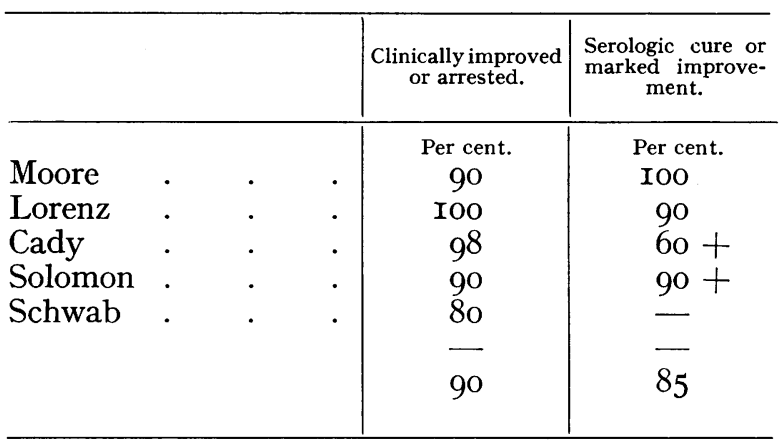

There was only one patient with meningo-vascular syphilis in the present series. Previous therapy consisted of six injections of neoarsphenamine and thirteen of bismuth. Seventy-five injections of tryparsamide were given, and the patient when last seen had been clinically improved, but only the cells in the spinal fluid had been reduced to normal. The protein, Wassermann and colloidal mastic were unchanged.

(3) Tabes dorsalis.

Results obtained by various Investigators

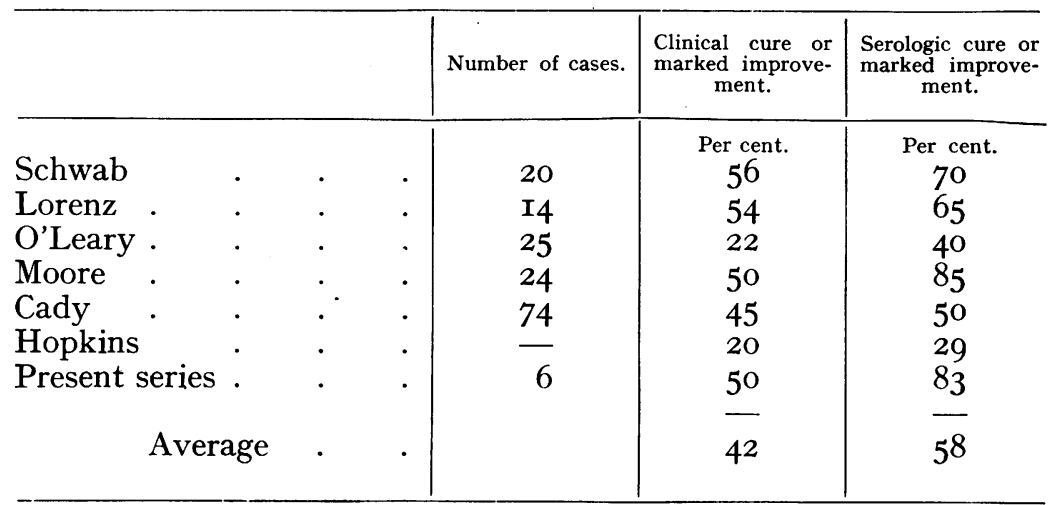

Tryparsamide is less effective in Tabes dorsalis than in other froms of neurosyphilis. There is a considerable discrepancy, as the above table indicates, between the clinical and the serologic results. Tabes dorsalis is a late degenerative process with permanent nerve damage. The tryparsamide arrests the active syphilitic process, as is shown by the higher percentage of serologic reversals, 


\section{TRYPARSAMIDE IN TREATMENT OF SYPHILIS}

but the impairment of function is caused by previous nerve damage, and clinical progression is the rule. Solomon states that ".Cases with marked degeneration do not respond well. A completely negative spinal fluid, indicating a burnt-out process, as is present in some of the late clinically active cases, makes the prognosis even less satisfactory. Yet tryparsamide is of definite value, and should be given a thorough trial in selected cases, as clinical improvement sometimes occurs after many months of therapy."

(4) General Paresis.

Results obtained by various Investigators

\begin{tabular}{|c|c|c|c|c|}
\hline & & Number of cases. & $\begin{array}{c}\text { Clinical improve- } \\
\text { ment. }\end{array}$ & $\begin{array}{c}\text { Serologic improve- } \\
\text { ment. }\end{array}$ \\
\hline $\begin{array}{l}\text { Schwab and Cady } \\
\text { Moore } \\
\text { Holmes } \\
\text { O'Leary } . \\
\text { Hinsie and Blalock } \\
\text { Hopkins } \\
\text { Ebaugh and Dickson } \\
\text { Stokes and Wilhelm } \\
\text { Lorenz } \\
\text { Present series. }\end{array}$ & $\begin{aligned} & \cdot \cdot \\
& \cdot \cdot \\
& \cdot \cdot \\
& \cdot \cdot \\
& \cdot \cdot \\
& \cdot \cdot \\
& i \cdot \\
& \cdot \cdot \\
& \cdot \cdot \\
& .\end{aligned}$ & $\begin{array}{r}63 \\
57 \\
64 \\
65 \\
60 \\
52 \\
\text { II } 4 \\
\text { II } \\
37\end{array}$ & $\begin{array}{l}\text { Per cent. } \\
74 \\
77 \\
90 \\
60 \\
4 \mathrm{I} \cdot 7 \\
20 \\
29 \\
57 \\
54 \\
63 \\
- \\
57\end{array}$ & $\begin{array}{c}\text { Per cent. } \\
68 \\
83 \\
50 \\
53 \\
\frac{40}{40} \\
80 \\
40 \\
75 \\
59\end{array}$ \\
\hline
\end{tabular}

In paresis tryparsamide again seems to arrest, in a large proportion of cases, the active syphilitic process in the parenchymatous tissue. In general it may be stated that the percentage of clinical and serologic arrest varies inversely with the age of the patient, the duration of the parenchymatous involvement and the degree of preexisting damage. Stokes, in a previous report, predicted the relatively poor results that were to be obtained in patients with the late deteriorated types of general paralysis. Hinsie and Blalock, working with institutionalised paretics, found a considerable discrepancy between the clinical and serologic improvements, the percentage of serologic improvement being much higher. Solomon and Lorenz obtained serologic reversals in a large percentage of institutionalised paretics, but found a very low percentage of clinical improvement. The 


\section{BRITISH JOURNAL OF VENEREAL DISEASES}

active process had been checked, but the past damage was irreparable. On the other hand, Stokes and Solomon have observed that juvenile paresis, a fairly late and extensive type of involvement, responds well clinically to tryparsamide, although the spinal fluid often cannot be reversed to negative.

Comparison of Clinical Improvement in Early and in Late Paresis

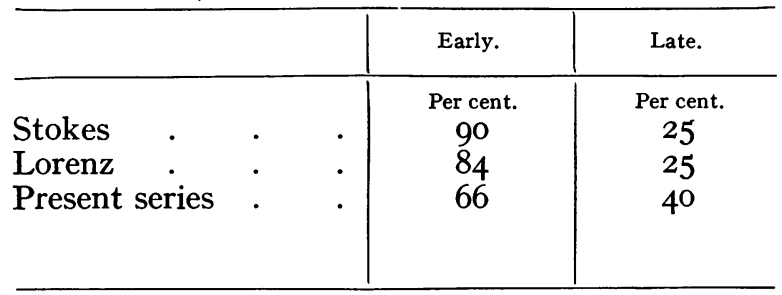

Women, as Hinsie and Blalock have noted, respond more favourably than do men. In the present series 62 per cent. of the eleven women underwent a complete serologic and clinical cure, while in only 46 per cent. of the men was complete serologic and clinical cure obtained.

Serologic Results in Spinal Fluid in General Paresis in Present Series

\begin{tabular}{|c|c|c|c|c|c|c|c|}
\hline \multirow{2}{*}{ Type. } & \multirow{2}{*}{$\begin{array}{l}\text { No. } \\
\text { cases. }\end{array}$} & \multirow{2}{*}{$\begin{array}{c}\text { Compl. } \\
\text { reversal } \\
\text { to } \\
\text { negative. }\end{array}$} & \multicolumn{4}{|c|}{ Reduction. } & \multirow{2}{*}{ Unchanged. } \\
\hline & & & Protein. & Cells. & Wass. & \begin{tabular}{|c} 
Coll. \\
mastic.
\end{tabular} & \\
\hline \multirow{6}{*}{$\begin{array}{l}\text { Asymptomatic } \\
\text { Early or moderately ad- } \\
\quad \text { vanced } \\
\text { Tabo-paresis } \\
\text { Late paresis } \\
\text { Juvenile paresis }\end{array}$} & 8 & $\begin{array}{c}\text { Per cent. } \\
66\end{array}$ & $\begin{array}{c}\text { Per cent. } \\
\text { I } 7\end{array}$ & $\begin{array}{c}\text { Per cent. } \\
\text { I } 7\end{array}$ & $\begin{array}{c}\text { Per cent } \\
\text { I } 7\end{array}$ & $\begin{array}{c}\text { Per cent } \\
\text { I } 7\end{array}$ & $\begin{array}{l}\text { Per cent. } \\
\quad \text { I } 7\end{array}$ \\
\hline & I 8 & 56 & I 8 & 29 & - & - & 15 \\
\hline & 6 & 50 & 33 & 33 & 16 & I6 & I 7 \\
\hline & 4 & None & 50 & 50 & 25 & - & 50 \\
\hline & I. & None & 一 & - & 一 & 一 & 100 \\
\hline & 37 & 50 & & & & & \\
\hline
\end{tabular}

As the above table indicates, the more advanced and the more extensive the process, the lower is the percentage of serologic improvement. The clinical response in juvenile paresis was excellent, there being a marked weight gain, feeling of well being, and increase in mental acuity. But there was no improvement in the spinal fluid after I29 injections of tryparsamide. 


\section{TRYPARSAMIDE IN TREATMENT OF SYPHILIS}

\section{Prolonged Treatment with Tryparsamide}

As is well known, clinical improvement occurs early during the course of treatment with tryparsamide; improvement of the spinal fluid takes place much more slowly. The initial changes are reductions in the number of cells and in the amount of protein ; reduction of the colloidal reaction and of the Wassermann test takes place more slowly.

Effect of Varying Amounts of Tryparsamide upon the Spinal Fluid in General Paralysis

\begin{tabular}{|c|c|c|c|c|c|c|c|}
\hline & & \multirow{2}{*}{$\begin{array}{l}\text { No. } \\
\text { cases. }\end{array}$} & \multirow{2}{*}{$\begin{array}{c}\text { No. } \\
\text { injections. }\end{array}$} & \multicolumn{4}{|c|}{ Per cent. rendered negative. } \\
\hline & & & & Cells. & Globu- & Wass. & Colloidal test. \\
\hline $\begin{array}{l}\text { Stokes and Wilhelm } \\
\text { Early paresis }\end{array}$ & & 21 & 20 & $7 \mathrm{I}$ & 20 & I0 & \\
\hline Late paresis & & 23 & 20 & I00 & 30 & 13 & \\
\hline Tennent * & & II & $50-100$ & 40 & 40 & 20 & 40 \\
\hline Bunker & & 7 & $75-115$ & - & 100 & o & \\
\hline Solomon and Viets $\dagger$ & $i$ & $\begin{array}{l}5 \\
5\end{array}$ & $\begin{array}{r}75^{-125} \\
\mathrm{I} 25^{-1} 80\end{array}$ & $\begin{array}{l}80 \\
80\end{array}$ & $\begin{array}{l}20 \\
60\end{array}$ & $\begin{array}{l}80 \\
60\end{array}$ & $\begin{array}{l}20(\text { Red. in 8o) } \\
60(", " 40)\end{array}$ \\
\hline
\end{tabular}

Moore, Stokes, O'Leary and Solomon especially have insisted that treatment with tryparsamide must be prolonged. Solomon has cited instances in which serologic reversal to negative has taken place only after the twohundredth injection of tryparsamide. He has given more than 300 injections, over a period of more than eight years, in resistant cases, and considers that complete reversal of the spinal fluid to negative is the only reliable sign of cure.

Accordingly, an effort was made in the present study to determine the effect of prolonged treatment with tryparsamide. The spinal fluid findings were plotted, first against the number of injections given to the whole group, and second against the number of injections given in the different clinical types of general paresis. In neither instance was there any definite correlation be-

* Seven of these eleven cases failed to improve with tryparsamide and were treated with malaria. Of these seven, the spinal fluid became negative in only three.

$\dagger$ Of this group the spinal fluid became negative in only three cases, although the clinical results were very good. The spinal fluids of the other seven cases were all improved, but in two instances 148 and 183 injections of tryparsamide failed to reverse the spinal fluid Wassermann reaction to negative. 


\section{BRITISH JOURNAL OF VENEREAL DISEASES}

tween the serologic response and the number of injections given. There seems to be some unknown factor in many cases of general paralysis which determines the type of response to tryparsamide therapy. Occasionally tryparsamide will produce neither clinical nor serologic improvement in cases in which it would seem to be the ideal method to use. In this series were three patients, one with early clinical paresis and two with asymptomatic paresis, who simply would not respond to Ioo injections of tryparsamide.

\section{The Question of Serologic and Clinical Relapse}

In this series are five cases of relapse. Two were those of early neuro-syphilis, already discussed ; the third case, one of early paresis, after having received forty injections of tryparsamide, was placed on a rest interim of six months. A spinal fluid examination after the rest revealed a paretic type of serologic relapse. After thirty more injections of tryparsamide the spinal fluid findings were unchanged. After her ninety-fourth injection she became very excitable and mentally confused, but then lapsed from view, preventing further observation. The fourth case was one of early paresis, who had been discharged as well (clinically and serologically) after seventy-one injections. He returned three years later complaining of speech difficulties, nervousness and poor memory. A spinal fluid examination revealed a paretic type of serology-Wassermann 4444, globulin four plus, cells six and colloidal mastic 55543r rooo. He subsequently lapsed from view. The last case was one of moderately advanced paresis. He received seventy-nine injections of tryparsamide, following which his spinal fluid had become negative and his clinical status had improved markedly. Ten months later a routine blood Wassermann test was returned strongly positive. As it had been negative for the previous year another spinal fluid examination was made, with the following result: Wassermann 4444, cells I6, globulin four plus, colloidal mastic 5555421000. His clinical status at the time was good, and after preparatory treatment with mercury and iodides he was given eight injections of tryparsamide. He then lapsed from view. Two months later he was admitted to the mental division of the hospital with marked mental Io6 
deterioration and confusion. He was subsequently given malarial therapy, with some clinical but no serologic improvement.

In the three cases just cited there was no intercurrent infection, either general or focal. There was no instance of severe nervous strain. And so here again, and for no apparent reason, the response to prolonged treatment with tryparsamide could not be predicted by a careful selection of patients in whom this method of therapy would seem to be ideal.

Many investigators (Jahnel, Grimaldi, Sioli, Hall, Belezky and Grant) have stated that there is a definite correlation between the clinical course of general paralysis and the spirochætes in the brain cortex. These spirochætal showers, or crises, are most frequently observed in the acute fulminating and in the juvenile types of paresis. Hauptman, however, has observed that in patients dying with acute seizures spirochætes are apt to be few in number, or may be actually absent. He believes that the seizure is an anaphylactic one and is evidence of true allergic sensitivity. On the other hand, some of the cases of intense spirochetosis such as Dieterle has described seem to be entirely accidental autopsy findings.

Grant and Aberol found very few spirochætes in the brains of cases treated with tryparsamide or malaria and dying from other causes. In the acute fulminating forms, when such therapy was ineffectual, many spirochætes were found. It may be, then, that the presence of large numbers of spirochætes in the brain increases the resistance of the disease process to tryparsamide therapy, but before this can be definitely accepted, the conceptions of individual immunity and susceptibility, of bacterial allergy, and of the neurotropic strains of the spirochæte, must first be clarified.

\section{Tryparsamide Therapy and the Blood Wassermann REACTION}

There is one other unexplained phenomenon which often occurs during the course of tryparsamide therapy. This is the frequently observed reversal to negative of the blood Wassermann reaction. It sometimes occurs early, sometimes after two or more years of treatment. 


\section{BRITISH JOURNAL OF VENEREAL DISEASES}

Moore states that " tryparsamide has little or no effect on the blood Wassermann reaction." Although I have no way of proving the converse, I believe that the spirochætes in the brain may be partially if not entirely responsible for the positive blood Wassermann. In the more fulminating type of case the spirochætes are greatly increased in number, the reaction to them is more intense and the blood Wassermann reaction is usually strongly positive. On the other hand, when tryparsamide has actually effected the disappearance of the spirochætes from the cortical tissue the blood Wassermann usually becomes negative. In this connection it may be noted that improvement in the blood Wassermann reaction roughly parallels that in the spinal fluid, and a serologic relapse in the spinal fluid is usually, although not always, accompanied by a corresponding one in the blood.

It is interesting to note that in cases of paresis resistant to tryparsamide not only does the spinal fluid Wassermann reaction remain strongly positive, but the protein and the cells of the spinal fluid are rather constantly increased.

Most of the cases in the present series also received bismuth therapy. This may have had some effect on the blood Wassermann reaction, especially if there were active antibody-forming centres outside of and irrespective of the central nervous system. Lastly, one must not forget the spontaneous tendency of the blood Wassermann reaction to become negative. While this factor can, I believe, be minimised in cases in which the involvement is primarily of the central nervous system, it must be kept in mind as a possible factor in such instances.

\section{Percentage Reversal of Blood Wassermann Reaction}

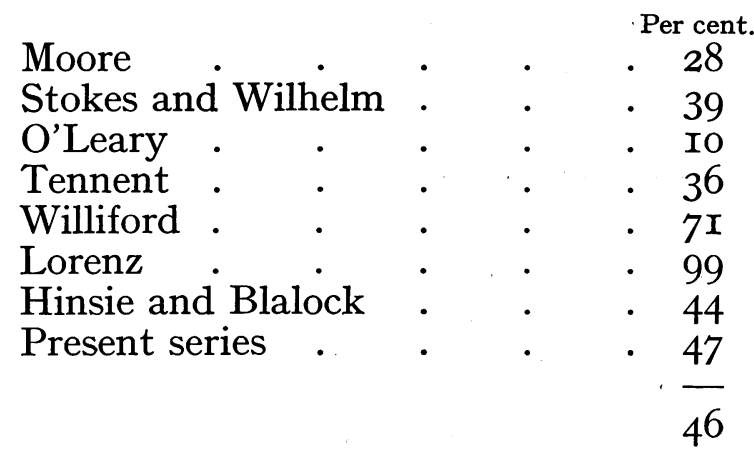




\section{TRYPARSAMIDE IN TREATMENT OF SYPHILIS}

\section{Action of Tryparsamide upon the Optic Mechanism}

Tryparsamide has, as is well known, a definite toxic action on the optic nerve mechanism, producing in a small proportion of cases a toxic amblyopia. Mild degrees of damage are accompanied only by subjective symptoms, the most common of which are failing, dim or dazzling vision and flashes of light, clouds or flickering before the eyes. The more severe degrees of damage are accompanied by objective signs, viz. : (I) diminution of visual acuity ; (2) constriction of the visual fields and, less important, (3) beginning pallor of the nerve head.

Percentage of Eye Damage by Tryparsamide*

\begin{tabular}{l|c|c|c|c|c}
\hline & No, cases. & $\begin{array}{c}\text { Per cent. of } \\
\text { eye reac- } \\
\text { tions. }\end{array}$ & $\begin{array}{c}\text { Subjective } \\
\text { symptoms. }\end{array}$ & $\begin{array}{c}\text { Objective } \\
\text { findings. }\end{array}$ & $\begin{array}{c}\text { Permanent } \\
\text { eye injury. }\end{array}$ \\
\cline { 1 - 5 } Previous authors. & 986 & $8 \cdot 0$ & $6 \cdot \mathrm{I}$ & $4 \cdot 5$ & $\mathrm{I} \cdot 6$ \\
\hline Present series . & 75 & $8 \cdot 3$ & $6 \cdot 6$ & $4 \cdot 5$ & $\mathrm{I} \cdot 3$ \\
\hline
\end{tabular}

The possibility of optic injury can be reduced to a minimum by a careful ophthalmologic control for the first ten weeks of therapy. This consists of a careful perimetric examination of the visual fields, the taking of visual acuity and an examination of the nerve head. Optic injury is rarely produced by tryparsamide after the tenth injection. The subjective symptoms are important warning signs and call for a repeated and careful search for signs of objective damage, and discontinuance of the drug for thirty days. When only slight signs of objective damage have appeared and further use of the drug seems urgently to be indicated, tryparsamide is only temporarily withheld (permanently, however, if damage is severe) and sodium' thiosulphate is given intravenously. For marked field constriction, Casten has recommended forced spinal drainage as described by Kubie. This consists of two to four lumbar punctures performed at intervals of two to four days. At each puncture Ioo to 200 c.c. of spinal fluid is removed, while the patient simultaneously

* Compilation of estimations by Woods and Moore, Lillie, O'Leary, Wile, Lorenz, Stokes and Wilhelm, Schwab and Cady, Ebaugh and Dickson, Solomon, Holmes and Tennent. 


\section{BRITISH JOURNAL OF VENEREAL DISEASES}

receives a hypotonic solution intravenously. We have had no experience of this form of treatment.

The exact cause of the eye damage is unknown. Many authors (Stokes, Moore, O'Leary) feel that the toxic action of tryparsamide is increased when the optic nerve is devitalised by pre-existing damage. Lillie, on the other hand, has stated that tryparsamide is no more injurious to the optic nerve than is arsphenamine (606). Young, Pearce and Loevenhart suggested that a too rapid resolution of the granulomatous tissue of neuro-syphilis may elaborate toxins which may produce or aggravate a preexisting optic lesion.

Sattler, Birch-Hirschfeld and Igersheimer have shown that eye damage by the pentavalent type of arsenical remedies (atoxyl) is done principally to the third neurone of the optic nerve. Sattler stated that the poison had its first point of attack on the third neurone, i.e., in the portion from the ganglion cell layer of the retina to the external geniculate body. Schwalbe believed that tryparsamide was concentrated in the spinal fluid, then reached the optic nerve viâ the subvaginal space, which communicates with the subarachnoid space. The spinal fluid surrounds the optic nerve from the lamina cribrosa to the optic foramen, the point of reflection of the brain membranes over the optic nerve. As the point of contact with the spinal fluid corresponds to that portion of the nerve which is most affected, it is conceivable that the damage is done in this manner. If the optic nerve has been previously damaged, it may be that a Herxheimer reaction in these involved areas may be responsible for the consequent symptoms which we term toxic amblyopia. This belief has crystallised into a gradual therapeutic approach with mercury, iodide and bismuth, followed by an initial I-gm. dose of tryparsamide. This gradual approach, however, has not always been successful, as will be shown in the following statement on optic atrophy. Lazar has recently suggested that the toxicity of tryparsamide may be an allergic type of reaction, depending on a specific anaphylactic reaction to the tryparsamide itself.

In the present series, subjective symptoms were observed in nine patients. In seven instances there were no accompanying objective signs, and tryparsamide therapy was resumed after a two-week interval. In two instances subjective symptoms were warning signals of 


\section{TRYPARSAMIDE IN TREATMENT OF SYPHILIS}

beginning objective damage. . The first patient complained of blurring and fine flashes in front of the eyes. The visual fields were moderately constricted, and tryparsamide was withheld for two weeks. The symptoms and field constriction had by then disappeared, and tryparsamide therapy was resumed without further trouble. The second patient was a rapidly advancing case of paresis associated with gastric crises. Her spinal fluid had become definitely worse on bismarsen, she had become intolerant to old arsphenamine (6o6) and she was placed on tryparsamide. The vision began to fail in the left eye after the ninth injection of tryparsamide. The ophthalmologic examination was negative, and it was felt that she should receive the benefit of tryparsamide if she could tolerate it. She persistently complained (for eight weeks) of gradually failing vision, but only after the seventeenth injection was definite field constriction and diminution of visual acuity observed. Tryparsamide therapy was then discontinued permanently. Subsequent examinations by the ophthalmologists revealed that the atrophy was of the primary type. It gradually progressed in spite of intraspinal therapy, and at the time of writing the patient is receiving as a last resort fever therapy. Just what, if any, was the rôle of the tryparsamide in hastening this most disconcerting progression is difficult to determine.

Objective signs of damage were present in four instances in 75 cases. In one patient this was observed after the second injection of tryparsamide, and in the second after the fourth injection. Tryparsamide was withheld for two weeks, by which time the signs of injury had disappeared, and therapy was gradually resumed without further trouble. The third patient developed contracted fields after the tenth injection of tryparsamide, and the fields subsequently improved, but did not become normal again (although vision was unaffected), and so therapy with tryparsamide was not resumed. The last patient was one with previous primary optic atrophy due to syphilis, and will be reported fully in the following paragraph. One other patient deserves recording; he presented moderately constricted fields at the onset of treatment; vision was excellent, and the visual fields had become normal after the tenth injection of tryparsamide. 


\section{Tryparsamide Therapy in Optic Atrophy}

Cady, in I930, recorded the effect of tryparsamide in patients with pre-existing eye involvement and made the surprising observation that in 16 cases of primary optic atrophy due to syphilis I2 per cent. were definitely improved and 50 per cent. were arrested by tryparsamide therapy. In ten patients with contracted fields 60 per cent. were either arrested or improved. Lees, following the suggestion of Cady, has used tryparsamide in the treatment of $2 \mathrm{I}$ ' cases of syphilitic optic atrophy. 'In' over 50 per cent. of the cases he secured a complete arrest, and the patient was able to resume his occupation. There was no effect in 3 cases, and in 6 cases the tryparsamide was discontinued because of developing signs of further damage.

We have treated only 2 cases of optic atrophy with tryparsamide. One patient, who was almost completely blind when first seen, was unaffected by either twenty Swift-Ellis treatments or by fifty injections of tryparsamide. The other, who had a moderately advanced atrophy, suffered a marked field constriction after receiving $0.5 \mathrm{gm}$. tryparsamide, although he had previously received months of preparatory treatment with bismuth. Tryparsamide was permanently withheld, and the fields subsequently recovered to the degree obtaining when first observed.

Tryparsamide therapy of optic atrophy is still in the experimental stage, and should be carried out cautiously, if at all, and then only at the hands of those to whom an adequate ophthalmologic control is available.

\section{COMPLICATIONS OTHER THAN OCULAR}

The literature records few complications, probably in part from incomplete reporting. There has been one instance of exfoliative dermatitis, five of jaundice, one of hemorrhagic disease due to bone marrow change, two nitritoid reactions; and one Jarisch-Herxheimer reaction (acute irritability and mania). Recently Robinson reported a case of fixed tryparsamide eruption, the only one in the literature.

In this series there were two instances of vomiting 


\section{TRYPARSAMIDE .IN TREATMENT OF SYPHILIS}

after tryparsamide injection, but in neither instance was discontinuance of the drug necessary.

There was one case of jaundice associated with an enlarged liver. Tryparsamide therapy was subsequently resumed without further trouble.

There was one instance of the so-called Herxheimer effect, the patient becoming more irritable and nervous with successive injections. This effect disappeared after the tenth injection.

In the present series only one severe early reaction was observed. The patient, one with early asymptomatic paresis, began to have headaches after his injection of tryparsamide. This was first noted after the sixth injection and gradually became more severe. Immediately after the twenty-sixth injection, in spite of the use of the "Bezredka" technic and the preliminary injection of $\frac{1}{75}$ grain of atropine sulphate, he developed a severe typical nitritoid attack. Tryparsamide therapy was resumed after a five months' interval, but after the fourth injection he developed a second nitritoid attack, this one much more severe than the first and requiring the use of adrenalin. The patient refused further tryparsamide therapy.

There were two cases of early cardiovascular involvement, signs of which developed while the active process in the brain was slowly responding to treatment. In each case standard therapy for syphilis had previously been given, but in insufficient amounts. One case did not receive bismuth during the tryparsamide therapy, while the other patient received only twenty-six injections of a bismuth preparation. The lesion in each instance was an early aortitis. This well emphasises the importance of giving concomitant courses of an intramuscular bismuth preparation, especially in those patients who have not previously received an adequate amount of standard treatment for syphilis.

\section{Conclusions}

(I) Tryparsamide is an excellent drug in the treatment of late syphilis of the central nervous system.

(2) Clinical improvement occurs early, and the clinical outcome in cases of early paresis is roughly paralleled by the serologic outcome in the spinal fluid. 


\section{BRITISH JOURNAL OF VENEREAL DISEASES}

(3) This series confirms the well-known belief that the clinical outcome is in inverse ratio to the duration of the disease and to the amount of pre-existing damage.

(4) The response of the spinal fluid was in this series only very roughly in direct proportion to the amount by weight of tryparsamide given. It seemed to depend more on the duration of and the amount of previous damage done by the disease. Complete return of the abnormal cerebro-spinal fluid to normal was obtained in 66 per cent. of the cases of asymptomatic paresis, in 56 per cent. of those patients with moderately advanced paresis, in 50 per cent. of the cases of tabo-paresis and in none of the cases of late paresis. The spinal fluid findings remained strongly positive in one case of juvenile paresis.

(5) The spinal fluid was reversed to negative in approximately 50 per cent. of the present series, most of which were cases of asymptomatic or early paresis. Solomon found that the spinal fluid was returned to normal in 35 per cent. of a cross section of all types of paresis. This difference in percentage illustrates the advantage of instituting treatment in the asymptomatic stage of general paresis.

(6) Complete clinical arrest and return to normal of the spinal fluid occurred in 62 per cent. of the women, as compared with 46 per cent. of the men.

(7) The action of tryparsamide could not always be absolutely predicted, even in those instances in which it would seem to be the ideal type of therapy. In three such instances there was no improvement with tryparsamide.

(8) Rarely, as Ravaut has observed, ultimate reversal of the spinal fluid to normal occurs. One patient whose spinal fluid was strongly positive at the end of fifty injections of tryparsamide was again examined after a lapse of three years; the spinal fluid had become completely normal without further treatment.

(9) In one instance serologic relapse (of spinal fluid) was the forerunner of clinical relapse.

(Io) Permanent eye injury occurred in this series in I. 3 per cent. of cases. No complete amblyopia occurred.

(II) There were two instances of early aortitis developing during tryparsamide therapy.

(I2) One severe nitritoid reaction was observed. This is the second reported case in the literature. 


\section{TRYPARSAMIDE IN TREATMENT OF SYPHILIS}

\section{BIBLIOGRAPHY}

(I) Jacobs, W. A., and Heidelberger, M. : (a) Jour. Am. Chem. Soc., 41, I68I, I9I7 ; (b) Jour. Am. Chem. Soc., 41, I587, I9I9.

(2) Brown, W., and Pearce, L. : (a) Jour. Exp. Med., 33, I93, I92I ; (b) J.A.M.A., 82, 5, I924 ; (c) New York State Jour. Med., 24, 75I, I924.

(3) LoRenz, W. F., et al.: (a) Wisconsin Med. Jour., 20, 336, I922 ; (b) J.A.M.A., 80, I497, I923; (c) Am. Jour. Med. Soc., 168, I57, I924; (d) J.A.M.A., 90, I285, I928 ; (e) Wisconsin Med. Jour., 29, 372, I930.

(4) Pearce, L.: Monographs of the Rockefeller Institute for Medical Research No. 23, August I5th, I930.

(5) Voegthen, Smith, Dyer and Thompson: Public Health Dept., 38, I003, I923.

(6) Moore, J., Robinson, H., and Keidel, A. : J.A.M.A., 82, 528, I924.

(7) Woods, A., and Moore, J. : J.A.M.A., 82, 2I05, I924.

(8) Moore, J., Robinson, H., and Lyman, R. : J.A.M.A., 83, 888, I924.

(9) Moore, J., and Sutton, I. : Jour. Nerv. \& Ment. Dis., 63, 569, I926.

(ro) Young, A., and Loevenhart, A. : J. Pharm. \& Exp. Ther., 23, I07, I924.

(II) Editorial, British Med. J., i., 537, I924.

(i2) Cheiresse, T. : (a) Presse Med., 32, 303, I924; (b) Presse Med., 32, 886, I924.

(I3) Guillain, G., and Gerst, L. : Bull. Acad. de Méd., Paris, 92, 850, I924.

(I4) Mehrtens, H., Kolos, F., Marshall, H. : Arch. Neur. and Psych., 12, 67, I924.

(I5) Ebaugh, F., and Dickson, R. : J.A.M.A., 83, 803, I924.

(I6) Lillie, I. : J.A.M.A., 83, 809, I924.

(I7) Solomon, H.: J. Nerv. \& Ment. Dis., 59, 299, 1924.

(I8) Solomon, H., and Veits, H. : (a) J.A.M.A., 83, 89I, I924;

(b) J.A.M.A., 85, 329, I925.

(I9) Solomon, H., and Berk, A.: Am. J. Syph., 12, 445, I928.

(20) Solomon, H.: Ann. Int. Med., 3, 447, I929.

(2I) Solomon, H., and Epstein, S. : Nere York State J. Med., 31, IOI2, I93I.

(22) Solomon, H. : (a) J. Urol. \& Cut. Review, April, I932 ;

(b) J. Nerv. \& Mental Dis., 78, 283, I933.

(23) WILE, U., and WIEDER, L.: (a) J.A.M.A., 83, I824, I924; (b) J.A.M.A., 84, I7IIO, I923.

(24) Schwab, S., and CADY, L. : (a) Arch. Neurol. \& Psych., 13, 8o, I925 ; (b) Amer. J. Syph., 11, I, January, I927.

(25) Fordyce, J., Rosen, I., and Meyers, C. : (a) Am. J. Syph., 8, 377, July, I924; (b) Am. J. Syph., 8, 6I9, October, I924.

(26) Fordyce, J., and Myers, C.: Am. J. Syph., 9, 490, July, I925.

(27) CADy, L. : Ill. Med. Jour., 57, I9, January, I930.

(28) Stokes, J., and Wilhelm, L. : Arch. Derm. \& Syph., 11, 579, I925. 


\section{BRITISH JOURNAL OF VENEREAL DISEASES}

(29) Stokes, J., and Chambers, S. : Am. J. Med. Soc., I75, May, I928.

(30) Schwab, S. M. : Clin. No. Amer., 9, I43, July, r925.

(3I) CADY, L., LEE, D., and Alvis, B. : J.A.M.A., 86, I84, I92̇6.

(32) O'Leary, P., and Becker, S.: Med. J. E Record, 123, 305, I926.

(33) Claude, H., and Targuola, R. : Compt. Rend. Soc. de Biol., 91, 527, I924.

(34) O'Leary, P. : Proc. Staff Meeting Mayo Clinic, 4, 127, I929.

(35) O'LeARY, P., and Brunsting, L.: J.A.M.A., 94, 452, I93o.

(36) LEEs, D.: (a) Brit. Med. J., July, I925; (b) Trans. of Ophth.

Soc. of United Kingdom, Vol. lii., 203, I933.

(37) Casten, V.: New Eng. Med. Jour., 202, 676, I930.

(38) Osborne, E., et al. : Arch. Derm. \& Syph., 25, 419, 1932.

(39) Hinsie, L., and Blalock: Am. Journ. Psychiat., 11, 54I, I93i.

(40) CoRnwall, et al. : Arch. Neur. \& Psychiat., 25, I37, I93I.

(4I) Tennent, T. : J. Med. Sciences, 7\%, 86, I93I.

(42) Holmes, M.: U.S. Vet. Bur. M. Bull., 5, 335, I929.

(43) Hopkins, H. H. : Archives Int. Medicine, 52, 66, I933.

(44) Robinson, A. J. : Fixed Tryparsamide Eruption, Am., Jour. Syph., October, I933.

(45) Ravaut, P.: Monde Méd. Paris, 40, 566, June Ist, I93o.

(46) Bunker, H. : Am. Jour. Med. Sci., 175, 265, I928.

(47) Schwalbe : Quoting Roemer and Foster, Text-book of Ophthalmology.

(48) Sattler, C. H. : Arch.f. Ophth., 81, 546, I9I2.

(49) Birch-Hirschfeld, A., and Koster, G.: Arch.f. Ophth., 73, 403, I9IO.

(50) Igersheimer, J. : Arch.f. Ophth., 71, 379, 1909.

(5I) Dieterle, R. : (a) Am. Jour. Psychiat., Vol. 7, No. 4, January, I928 ; (b) Personal Communication to the Author.

(52) JAHNEL, F.: Handbuch der Haut und Geschlechtskrankheiten, Vol. 17, Part I.

(53) Jahnel, F. : Zeitschr. f. d. ges. Neurol. u. Psychiat., 3, 3ro, I92I, and 76, I66, I922.

(54) JAhNel, F. : Dermatol. Ztschr., 25, 604, October; I9I7.

(55) Grant, A., and Aberol, M. : Jour. Med. Sci., 73, 595, 1927.

(56) Grimaldi : Ann. de Neurol., 39, 22, I922.

(57) Moore, J. : “Textbook, The Modern Treatment of Syphilis," p. 367 .

(58) Kubie, L. : Arch. Neurol. and Psychiat., 19, 997, I923. 